\title{
The Larvæ of the Decapoda Macrura and Anomura of Plymouth.
}

\author{
By \\ Gladys E. Webb, \\ Assistant in Zoology, University College, London; late Temporary Assistant Naturalist \\ at the Marine Biological Laboratory, Plymouth.
}

With Plates I-IV.

THE larvæ of the Decapod Macrura occur throughout the year in the townettings taken in Plymouth Sound; while during the summer months they form an important and conspicuous feature of the coastal plankton.

In only a few cases have their life-histories been fully worked out, owing probably to the difficulty of rearing the larvæ under artificial conditions; and the literature on the subject is consequently both scanty and scattered. It has therefore been suggested that a brief review of the larvæ already described, together with a few additional ones which have been identified during two years' examination of the Plymouth plankton, from 1917-1919, might be of some use to future investigators.

The object of the present paper is to enable future workers to see at a glance how far these forms have been investigated, and especially to facilitate the identification of the living larvæ from the tow-nets.

No attempt has been made to describe the appendages in detail, as such particulars can generally be found in the literature cited. A general outline drawing is given of the more important forms in their first larval stage, and a figure of the telson and uropods in the fourth or last larval stage is also shown.

As the coloration of the larva is often of great assistance in identifying the living animal, it is here described rather fully, and, whenever possible, the drawings and the colour notes have been made from the living larva. In cases where no direct observations were available the colour descriptions are quoted from other authorities.

The larvæ of three families of Decapods commonly found at Plymouth -namely, the Hippolytidæ, the Galatheidæ and the Paguridæ-are known as yet very incompletely; and even when the larvæ have been described, it is often very doubtful whether they have been referred to their correct species. In such cases, therefore, a typical larva has been described, without attempt to refer it to a particular species.

The nomenclature adopted throughout this paper is that used in the Plymouth Marine Invertebrate Fauna List (1904). 
I am indebted to Dr. Calman, of the British Museum, and Dr. E. J. Allen, of the Plymouth Laboratory, for valuable advice on various points, and to Miss M. V. Lebour, D.Sc., for her assistance to me throughout, and particularly for her help in the rearing of the larvæin the Laboratory.

\section{Family PALAMONIDA.}

Species recorded in Plymouth Marine Invertebrate Fauna :-

Leander serratus (Pennant).

Leander squilla (Linnæus).

Palamonetes varians (Leach).

Features Characteristic of these Larva of Palæmonide.

Rostrum. Long, slender, and pointed, reaching almost to end of first antenna.

Eyes. Sessile in early stages, later stalked and movable.

First Antenna. Long and straight (cf. Pandalidæ).

Telson. In early stages spatulate, truncated, bearing three plumose setæ at each corner and eight at regular intervals along the posterior margin. In later stages telson becomes long and narrow.

\section{Distinguishing Features of the Four Larval Stages.}

Stage I (First Zooea Stage) :-

(a) Caudal plate simple.

(b) Uropods absent.

(c) Three pairs of setose exopodites.

Stage II (Second Zocea Stage) :-

(a) Caudal plate unchanged.

(b) Uropods absent.

(c) Five pairs of setose exopodites.

Stage III (Intermediate Stage) :-

(a) Telson narrower, cleft slightly in middle line.

(b) Outer uropods well developed and armed with spines; inner uropods present, but small and spineless.

(c) Six pairs of setose exopodites.

Stage IV (Mysis Stage) :-

(a) Telson long and narrow.

(b) Both pairs of uropods well developed and armed with spines.

(c) Six pairs of setose exopodites. 


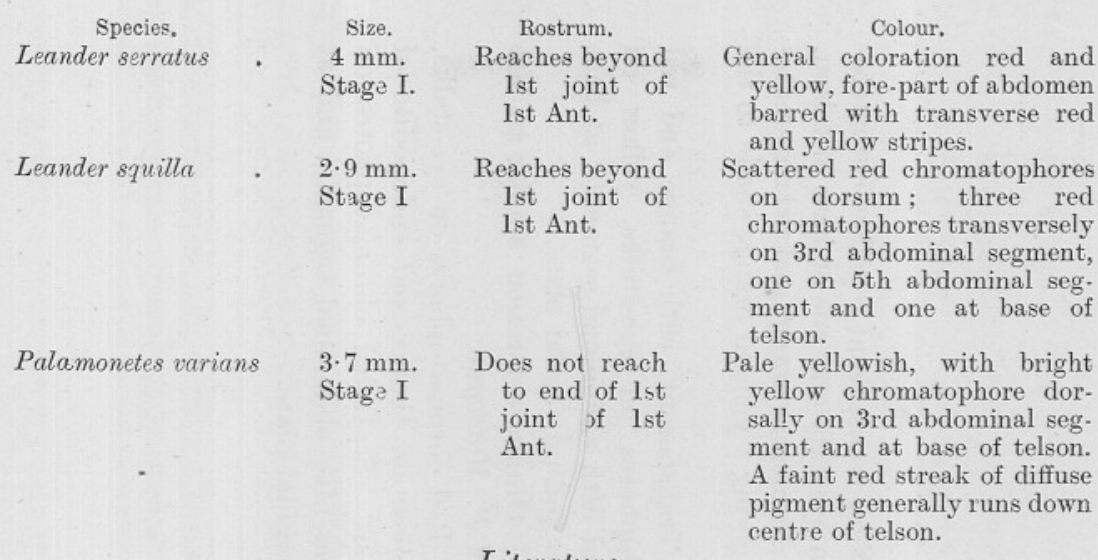

Couch, R. Q. 1844.

Mayer, P. 1881.
Sollaud, E. 1912.

Thompson, J. V. 1836.

Family PANDALIDA.

Species recorded in Plymouth Marine Invertebrate Fauna :-

Pandalus Montagui Leach.

Pandalus brevirostris Rathke.

Other larvæ occurring at Plymouth, adult not recorded from this district :-

Pandalus Bonnieri Caullery.

Features Characteristic of these Larva of Pandalid

Eyes. Sessile in early stages, later stalked and movable.

First antenna. Slightly concave on outer side in late stages.

Telson. Similar to that of Crangon vulgaris; rather deeply indented in middle line in early stages. In later stages telson becomes long and narrow, similar to that of Palæmonidæ.

Coloration. In early stages very transparent, but later there is a great development of red and orange chromatophores, especially on the thorax, and developing endopodites of thoracic limbs.

\section{Distinguishing Features of the Four Larval Stages.}

Stage I. Caudal plate simple, bearing fourteen spines; uropods absent.

Stage II. Caudal plate simple, bearing sixteen spines; uropods absent.

Stage III. Telson and outer uropods well developed and armed with spines; inner uropods present, but small and spineless.

Stage IV. Both pairs of uropods well developed and armed with spines.

\section{Literature.}

Sars, G. O. 1900. 
Species

Pandalus Montagui.

Hatched in Laboratory.

Pandalus brevirostris.

Pandalus Bonnieri.

N.B.-In Stage $I$ there is a median dorsal spine behind the rostrum.

In Stage II this is replaced by two curved, dorso-lateral horns. (Sars, 1900.)
$4 \mathrm{~mm}$.

Stage $I$.

$2 \cdot 1 \mathrm{~mm}$.

Short and pointed.

Stage $I$.

Long and slender, reaching almost to end of first antenna.
Colour.

Stage $\vec{i}$. Very transparent; yellow chromatophore on eyestalk and one at base of telson. Stage IV. Numerous orange and red chromatophores, giving a general orange shade to the larva.

Stage I. Transparent, with orange and red chromatophores on eye-stalks, yellow on third and fifth abdominal segments, at base of telson and on caudal plate.

Stage $I V$. Orange coloration similar to late stages of $P$. Montagui.

Stage II. Red chromatophores on eye-stalks, deep yellow on thorax and endopodite of nereiopods. Scattered chromatophores on third and fifth abdominal segments and at base of caudal plate. 


\title{
Family HIPPOLYTID在.
}

\section{Species recorded in Plymouth Marine Invertebrate Fauna :-}

\author{
Hippolyte fascigera Gosse. \\ Hippolyte varians Leach. \\ Hippolyte viridis (Otto). \\ Spirontocaris Cranchi (Leach).
}

The family Hippolytidæ is represented at Plymouth by the above four species. Of these the larval development of one only, Hippolyte varians Leach, has been fully described (Sars, 1911), and although the larvæ of this genus occur fairly frequently in the plankton samples at Plymouth during the summer months, they have not yet been described in detail.

They are distinctly smaller than the larvæ of the other families of Decapods at Plymouth, Hippolyte varians in its first zœa stage measuring only $1.5 \mathrm{~mm}$. in length. This larva, which may be considered typical of the genus, bears a strong resemblance to certain members of the Crangonidæ, e.g. Crangon vulgaris; the telson of $H$. varians and C. vul. garis in the first stage being almost identical, both in shape and armature (cf. Pl. I, Fig. 3, and Pl. II, Fig. 1).

The Hippolyte larva, however, is distinctly shorter and stouter in build than $C$. vulgaris; it has a more pronounced caridean bend, the abdomen is quite unarmed, the eyes are relatively much larger and the rostrum rather longer than in C. vulgaris.

The coloration consists of a luminous yellow shade over the thorax and part of the telson, with scattered orange and red chromatophores in certain definite positions, e.g. on the eye-stalks, base of rostrum, the first three and the fifth abdominal segments and the base of the telson.

The larva of Spirontocaris Cranchi is of a more slender character than $H$. varians, measuring about $2 \mathrm{~mm}$. in length in the first zœa stage; and the rostrum is very short or absent; but in other respects it closely resembles that of $H$. varians, and the distribution of the chromatophores, which are of a rather brighter red than in $H$. varians, is almost identical, although the larva is more hyaline in appearance, owing to the absence of the luminous yellow network on the thorax.

\section{Literature.}

Sars, G. O. $1911 . \quad$ Williamson, H. C. 1915.

Family ALPHEID E.

Species recorded in Plymouth Marine Invertebrate Fauna :Alpheus ruber Milne Edwards. Athanas nitescens (Leach). 


\section{Features Characteristic of these Larve of Alpheid e.}

Thoracic Legs. Last (fifth) pair elongated and styliform, carried pointing forwards beneath the body (not developed until third larval stage in Alpheus ruber).

For distinguishing features of the first four larval stages, see table given under Pandalidæ on page 387.

\section{Alpheus ruber Milne Edwards.}

The accounts of the larval stages of Alpheus ruber are very incomplete; a short description of the various larval stages, founded on material collected at Plymouth, is therefore given here.

Stage I. In the first stage the larva measures about $2.6 \mathrm{~mm}$. from the tip of the rostrum to the end of the swimming-plate. The body is somewhat compressed laterally, and the typical caridean bend in the third abdominal segment is quite distinct. There are three pairs of setose exopodites, one on each of the three pairs of maxillipeds, and the endopodite of the third maxilliped is rather long and slender and ends in a sharp point. Behind the third maxilliped are the rudiments of the first two pairs of thoracic legs, of which the first are already biramous. The terminal swimming-plate is of spatulate shape, armed around the posterior margin with fourteen strong setæ, and bearing a close resemblance to the caudal plate of Crangon vulgaris in the same stage.

Stage $I I$. The larva in this stage is very similar to that of the preceding stage, from which it differs in the following points:

Its length is now about $2.8 \mathrm{~mm}$. The endopodite of the third maxilliped terminates in a very long, slender spine, about twice the length of the exopodite. The use of this long spine is not clear, but it is apparently functionally replaced in the next larval stage by the fifth thoracic leg, which is there drawn out into a similar process, while that of the third maxilliped simultaneously disappears. The rudiments of the first thoracic legs are longer, and the swimming-plate is armed with sixteen spines, an additional pair having appeared in the middle of the posterior border.

Stage III. The length at this stage is about $3.2 \mathrm{~mm}$. The third pair of maxillipeds have lost the long spine on the endopodite, which now terminates in a short point. The exopodite of the first pair of thoracic legs is now setose, making four pairs of setose exopodites in all. Behind the first thoracic legs the rudiments of the second and third pairs are plainly visible. The fourth pair is not yet apparent; but the fifth pair, prematurely developed, each takes the form of a three-jointed process terminating in a long, slender spine which extends beyond the end of the first antenna in front, and is very similar to that found on the third maxilliped in the previous stage. These appendages are carried pointing 
forwards underneath the body, and appear to be characteristic of the larval stages of the Alpheidæ. The pleopods are still absent, but there are now two pairs of uropods, the outer pair fully developed and setose, but the inner small and unarmed. The telson is narrower, but armed with sixteen setæ, as in the previous stage.

Stage IV. The larva is rather shorter and stouter in this stage, measuring about $2.8 \mathrm{~mm}$. in length from rostrum to telson. The rudiments of all the thoracic legs are now present, the fifth pair still ending in a long spine reaching well beyond the first antenna. The pleopods are not yet distinct, the telson is longer and narrower, and both pairs of uropods are well developed and armed with plumose setæ.

The larval stages of Alpheus differ from those of most Decapods in that the fourth larval stage is not immediately followed by the first postlarval, resembling the adult form, but is succeeded by a series of stages during which the characters of the adult are acquired by degrees. At the fourth larval stage described above, the telson and uropods have reached a stage of development typical of this period of the larval life; but the thoracic legs and the pleopods are still comparatively little formed. During the following larval stages these appendages are further developed.

After the fourth larval stage the subsequent stages are not so sharply defined, but five further stages (V-IX) can be discerned, distinguished by the following points :-

Stage $V$.

Length about $2 \cdot 8 \mathrm{~mm}$.

Five pairs of pleopods, small but distinct.

Stage VI.

Length about $3.5 \mathrm{~mm}$.

Five pairs of setose exopodites-from the first maxilliped to the second thoracic leg.

Pleopods biramous, about the length of one abdominal segment.

Stage VII.

Length about $3 \cdot 6 \mathrm{~mm}$.

Thoracic legs distinctly larger and more developed.

Pleopods extending over about one and a half abdominal segments; divided into distinct base and two distal rami.

Stage VIII.

Length about $3.9 \mathrm{~mm}$.

First and second pairs of thoracic legs chelate; third and fourth pairs jointed.

Pleopods covering two abdominal segments. 
Stage $I X$.

Length about $4 \mathrm{~mm}$.

Spine on fifth thoracic leg absent (possibly broken in my specimens). Pleopods and thoracic legs fully developed, but still enclosed in the larval sheath.

The following colour notes were taken from a larva of the second stage : Pale yellow on eye-stalks, first antennæ, sides of thorax, third and fifth abdominal segments and the terminal swimming-plate. Bright red chromatophores on eye-stalks, first antennæ, base of rostrum, at junction of thorax and abdomen, on second, third and fifth abdominal segments. and on terminal swimming-plate.

\section{Athanas nitescens (Leach) (Pl. I, Figs. 4 and 8).}

Full descriptions of the later larval stages of this species have been given by Sars (1906), who believed the first stage figured by him (Pl. I, Figs. 1 and 2 ) to be the earliest free larval stages. Two younger larval stages have, however, been found in material collected at Plymouth in August and September, 1920, and that figured by Sars as the first therefore corresponds to the third larval stage of Alpheus or other Decapods. The first and second larval stages only are here described.

Stage I. The larva measures about $1.9 \mathrm{~mm}$. from the end of the first antennæ to the end of the swimming-plate, or $1.6 \mathrm{~mm}$. from the tip of the rostrum to the same spot. The thorax is less than half the length of the abdomen; the carapace is evenly rounded behind and ends in front in a short acute, median rostrum; the eyes are large and directed slightly forwards. The abdomen is long and slender, with a distinct caridean bend at the third segment, and ending in a flattened triangular swimming-plate armed with plumose setæ. There are no pleopods, the animal swimming actively through the water by means of the setose exopodites on the three pairs of maxillipeds.

The First Antenna is a simple unjointed process bearing at the end a short palp with tactile appendages, and on the inner side of the palp a stout plumose seta and several fine spines.

The Second Antenna consists of a basal joint prolonged on its inner border into a short spine and bearing an antennal scale, about half as long again as the base, bordered by eleven plumose setæ; and a small process on the inner side of the scale, tipped with a short serrate spine.

The Mandible is very small, apparently with a small palp.

The First Maxilla is small but bilobed, the masticatory lobe beset with a few weak setæ, and bears a rudimentary palp.

The Second Maxilla is a simple unjointed process tipped with a single 
seta, but showing indications of secondary lobes along its inner edge. The scaphognathite is not jointed off from the base, and bears three to five scattered marginal setæ.

The First Maxilliped consists of a basal portion bearing a seta-tipped. endopodite (not jointed off from the base), and a curved exopodite with two terminal plumose setæ.

The Second Maxilliped has a base with a short endopodite (unjointed), tipped with a stout serrate spine and a few weak setæ, and a curved exopodite with three terminal plumose setæ.

The Third Maxilliped has a basal part jointed off from the rest and bearing an endopodite about three-quarters the length of the exopodite, tipped with a serrate spine and a few slender setæ, and a curved exopodite with three terminal plumose setæ and one just below the tip.

The first thoracic leg rudiment is already biramous and about as long as the endopodite of the third maxilliped. There is no trace as yet of the second to the fourth thoracic legs, but the fifth is a well-developed uniramous process, fully as long as the first thoracic leg rudiment and carried pointing forward beneath the thorax.

Stage II. The second larval stage closely resembles the first, from which it differs in the following points: The length is $2 \mathrm{~mm}$. from first. antenna to caudal plate, or $1.7 \mathrm{~mm}$. from the rostrum to the same point.

The First Antenna consists of a long basal and a short terminal joint, bearing two palps, the outer and larger tipped with three tactile appendages, and the smaller with a single stout plumose seta. A slender seta also occurs at the outer margin of the proximal joint.

The First Maxilla has both masticatory lobe and palp tipped with setæ.

The Second Maxilla is tipped with two setæ, and bears three more along its inner edge.

The First Maxilliped has an endopodite distinct from the basal joint; the exopodite bears four terminal plumose setæ.

The Second Maxilliped has an endopodite which is indistinctly threejointed, and bears a second serrate spine on the inner edge; the exopodite ends in four plumose setæ.

The Third Maxilliped has a distinctly jointed endopodite with a serrate spine on the inner edge. The first thoracic leg rudiment is distinctly longer than in the previous stage, and very small rudiments of the remaining pairs of thoracic legs are also present. The fifth pair is well developed forming a process reaching forward beyond the first thoracic leg.

The Swimming-Plate is unchanged in shape, but bears an extra pair of small setæ in the middle of the posterior border, making sixteen setæ in all.

The following colour notes were taken from a larva of Stage II : The larva is almost perfectly transparent, with a few scattered red and yellow 
chromatophores very similarly distributed to those of Alpheus, namely, pale luminous yellow on the eyes, the first antennæ, at the base of the thoracic appendages, on the third and fourth abdominal segments and the terminal swimming-plate; while bright red chromatophores occur on the first antennæ, on the eye-stalks, between the eyes, on the third, fourth and fifth abdominal segments and at the base of the swimming-plate.

\section{Literature.}

Brooks, W. K., and Herrick, F. H., $\quad$ Lo Bianco, S. 1902. 1891.

Lo Bianco, S. 1904.

Coutière, H. $1 \varepsilon 99$.

Sars, G. O. 1906.

Coutière, H. 1907.

\section{Family CRANGONIDA.}

Species recorded in Plymouth Marine Invertebrate Fauna :-

Crangon Allmanni Kinahan.

Crangon vulgaris (Linnæus).

Egeon fasciatus Risso.

Egeon sculptus (Bell).

Pontophilus spinosus Leach.

Cheraphilus nanus (Kröyer).

Cheraphilus trispinosus (Hailstone).

Features Characteristic of these Larva of Crangonide.

Rostrum generally fused with carapace at base.

Eyes round, set rather close together, apparently continuous with carapace behind and on inner side; often somewhat swollen at base, resembling an acorn and cup.

Thorax short, sometimes very short in proportion to abdomen, e.g. P. spinosus.

Colour. Rather dense coloration, especially on inner antennæ; varies from pinkish brown to lemon-yellow.

For distinguishing features of the four larval stages, see table given under Pandalidæ on page 387 .

\section{Literature.}

Gurney, R. 1903 (i).

Gurney, R. 1903 (ii).
Sars, G. O. 1890.

Williamson, H. C. 1901. 


\begin{tabular}{|c|c|c|c|c|c|}
\hline Species. & Size. & Telson. & Abdominal Spines. & $\begin{array}{c}\text { Antennæ and } \\
\text { Setose Exopodites. }\end{array}$ & Colour. \\
\hline Crangon vulgaris. & $\begin{array}{l}\text { Slage I, } 2 \cdot 3 \mathrm{~mm} \text {. } \\
\text { Stage IV } 4 \cdot 7 \mathrm{~mm} \text {. }\end{array}$ & $\begin{array}{l}\text { Roughly triangular. } \\
\text { Slightly indented } \\
\text { in middle line. }\end{array}$ & $\begin{array}{l}1 \text { short median dorsal on } \\
\text { 3rd abd. seg. }\end{array}$ & $\begin{array}{l}\text { Short. } 4 \text { prs. setose } \\
\text { exopodites in } \\
\text { Stage } I V \text {. }\end{array}$ & $\begin{array}{l}\text { Scattered yellow and } \\
\text { brown chromato- } \\
\text { phores. }\end{array}$ \\
\hline Crangon Allmanni. & $\begin{array}{l}\text { Longer and thin- } \\
\text { ner than C. vul- } \\
\text { garis. } \\
\text { Stage IV, } 6 \mathrm{~mm} \text {. }\end{array}$ & $\begin{array}{l}\text { Similar to } C \text {. vul- } \\
\text { garis. }\end{array}$ & $\begin{array}{l}2 \text { short lateral on } 5 \text { th abd. } \\
\text { seg. }\end{array}$ & $\begin{array}{l}\text { Short. } 4 \text { prs. setose } \\
\text { exopodites in } \\
\text { Stage } I V .\end{array}$ & \\
\hline Egeon fascialus. & Stage I, $22 \mathrm{~mm}$. & $\begin{array}{l}\text { Similar to } C \text {. vul- } \\
\text { garis but more } \\
\text { indented. }\end{array}$ & $\begin{array}{l}2 \text { dorso-lateral on } 3 \text { rd seg. } \\
2 \text { small lateral on } 4 \text { th seg. } \\
2 \text { long lateral on } 5 \text { th seg. }\end{array}$ & $\begin{array}{l}\text { Moderate. } 5 \text { prs. } \\
\text { setose exopodites } \\
\text { in Stage IV. }\end{array}$ & $\begin{array}{l}\text { Dense brown and } \\
\text { yellow chromato- } \\
\text { phores, giving a } \\
\text { deep golden brown } \\
\text { colour. }\end{array}$ \\
\hline $\begin{array}{l}\text { Egeon sculptus. } \\
\text { Pontophilus spinosus. }\end{array}$ & $\begin{array}{l}\text { Larva unknown. } \\
\text { Stage } I, 6 \mathrm{~mm} \text {. }\end{array}$ & $\begin{array}{l}\text { Very deeply in- } \\
\text { dented-Y-shaped. }\end{array}$ & $\begin{array}{l}1 \text { long median dorsal on } \\
\text { 3rd abd. seg. } \\
2 \text { long lateral on 5th seg. }\end{array}$ & $\begin{array}{l}\text { Very long. } 5 \text { prs. } \\
\text { setose exopodites } \\
\text { in Stage IV. }\end{array}$ & $\begin{array}{l}\text { Yellow, pink and } \\
\text { brown chromato- } \\
\text { phores, giving } \\
\text { yellow colour by } \\
\text { reflected light. }\end{array}$ \\
\hline Cheraphilus nanus. & $\begin{array}{l}\text { Stage } I, 1.8 \mathrm{~mm} \text {. } \\
\text { Stage IV, } 3.3 \mathrm{~mm} \text {. }\end{array}$ & $\begin{array}{l}\text { Similar to } C \text {. vul } \\
\text { garis. }\end{array}$ & $\begin{array}{l}2 \text { short dorso-lateral on } \\
3 \text { rd abd. seg. } \\
2 \text { short lat. on } 4 \text { th seg. } \\
2 \text { short lat. on } 5 \text { th seg. }\end{array}$ & $\begin{array}{l}\text { Short. } 5 \text { prs. setose } \\
\text { exopodites in } \\
\text { Stage } I V .\end{array}$ & $\begin{array}{l}\text { "Golden-green back. } \\
\text { ground, greater } \\
\text { part of ventral sur- } \\
\text { face covered with } \\
\text { more or less intense } \\
\text { red-brown coat." }\end{array}$ \\
\hline Cheraphilus trispinosus & Stage I, $3 \mathrm{~mm}$. & $\begin{array}{l}\text { Similar to } C \text {. vul- } \\
\text { garis. }\end{array}$ & Absent. & $\begin{array}{l}\text { Short. } 5 \text { prs. setose } \\
\text { exopodites in } \\
\text { Stage IV. }\end{array}$ & $\begin{array}{l}\text { Very dense yellow } \\
\text { and brown chroma- } \\
\text { tophores especially } \\
\text { thick on thorax and } \\
\text { 1st } 3 \text { abd. segs., } \\
\text { giving dark yellow- } \\
\text { ish-brown colour. }\end{array}$ \\
\hline
\end{tabular}




\section{Family NIKID $\nRightarrow$.}

Species recorded in the Plymouth Marine Invertebrate Fauna :-

\section{Nika edulis Risso.}

I have not succeeded in identifying the larva of this species in the Plymouth plankton, and although the occurrence of the larval stages is recorded by Gurney in the Plymouth Marine Invertebrate Fauna, I do. not think any description of this larva has been published. Unfortunately Mr. Gurney was unable to supply me with any specimens.

\section{Family NEPHROPSID Æ.}

Species recorded in Plymouth Marine Invertebrate Fauna :-

Homarus vulgaris Milne Edwards.

The larva of the Lobster is hatched at a rather more advanced stage of development than is usual among Decapod larvæ. It is about $10 \mathrm{~mm}$. in length at the first stage, and already possesses all five pairs of pereiopods and six pairs of setose exopodites, although no pleopods are yet present. The telson is large and spatulate, with a strongly concave posterior border, which is beset with a row of small spines and one larger median spine. The exact number of larval moults has not been ascertained, but at least three well-defined larval stages may be distinguished.

\section{Distinguishing Features of Three Larval Stages.}

\section{Stage 1 .}

Length $10 \mathrm{~mm}$.

Rostrum large, triangular, pointed.

Pleopods absent.

Uropods absent.

Telson spatulate, concave posterior border.

Stage $I I$.

Length $14 \mathrm{~mm}$.

Rostrum beset with a few marginal spines.

Pleopods present, but small.

Uropods absent.

Telson not quite so concave behind.

Stage III.

Length $17-18 \mathrm{~mm}$.

Rostrum larger and more spinous. 


\section{Pleopods larger.}

Uropods. Two pairs present, fully armed.

Telson only slightly concave behind.

The following description of the coloration of the larva of Homarus vulgaris is translated from Sars (1874, p. 14) :-

"The colour is light yellowish, shading over more or less, on some parts of the body, to a luminous blue-green. But the body generally appears more intensely coloured by reason of the numerous star-shaped branching red-brown pigment spots, which are thickly crowded together on the carapace, as well as on the sides of the abdomen, and especially on the caudal plate. Also one notices similar but smaller pigment spots on the inner antennæ and the chelæ of the first pair of legs. The eye pigment is dark brown with glints of bluish green."

\section{Literature.}

Sars, G. O. 1874. Williamson, H. C. 1904.

Family SCYLLARIDF.

Species recorded in Plymouth Marine Invertebrate Fauna :Arctus ursus Dana.

Family PALINURID E.

Species recorded in Plymouth Marine Invertebrate Fauna :Patinurus vulgaris Latreille.

The larval form of both Arctus ursus and Palinurus vulgaris is a transparent flattened organism known as a Phyllosoma larva.

The thorax of the Phyllosoma is strongly compressed dorso-ventrally and forms a thin leaf-like plate, from beneath the margins of which spring the thoracic limbs.

The abdomen is extremely small and narrow, and devoid of pleopods or uropods in the early stages. The larval stages of these two species are very similar and have been somewhat confused, but apparently the chief points of difference are as follows :-

Arctus ursus.

1. Length $2 \mathrm{~mm}$. when hatched.

2. First pair of maxillipeds absent in Stage I.
Patinurus vulgaris.

1. Length $3 \cdot 1 \mathrm{~mm}$. when hatched.

2. First pair of maxillipeds present in Stage I in rudimentary condition. 
3. In young stages the first antenna longer than second antenna, but in later stages they are of almost equal length.

4. Reaches at least $24 \mathrm{~mm}$. length before losing the flattened form.

\section{Literature.}

Claus, 1863.

Cunningham, J. J. 1891.
3. In young stages the first antenna longer than second antenna, but in later stages the reverse is the case.

4. Reaches $21 \mathrm{~mm}$. length before losing the flattened form.

\section{Family GALATHEID $A$.}

Species recorded in Plymouth Marine Invertebrate Fauna :-

Galathea dispersa Spence Bate.

Galathea intermedia Lilljeborg.

Galathea squamifera Leach.

Galathea strigosa (Linnæus).

\section{Features Characteristic of these Larvæ of Galatheid}

Rostrum. Long, slender and pointed; reaches beyond first antennæ. Eyes. Large and oval.

Carapace. Terminated postero-laterally by a strong spine, fringed on either side by a row of smaller spines.

Telson. Large and spatulate; in early stages deeply cleft in middle line.

Coloration. Varies considerably, but there are generally bright red chromatophores on thorax, and some smaller ones on abdomen and telson. Thorax often shows a yellow or luminous green shade. Eyes tinged with green. Sometimes there is a red chromatophore on the first antenna.

\section{Distinguishing Features of the Four Larval Stages.}

Stage I. Caudal plate simple, bearing twelve spines; uropods absent.

Stage II. Caudal plate simple, bearing fourteen spines; uropods absent.

Stage III. Telson and outer uropods well developed and armed with spines ; inner uropods present, but small and spineless.

Stage IV. Both pairs of uropods well developed and armed with spines. 
I have been unable to identify the larva of Galathea strigosa with certainty, but the larvæ of the three remaining Plymouth species may be distinguished by the relative length of the terminal spine on the antennal plate and of the outermost spine on the telson.

These spines are longest in G. squamifera and shortest in G. intermedia.

In $G$. squamifera the spine on the antennal plate is more than half the length of the plate itself; while in $G$. intermedia it is about one-third the length of the plate.

The outermost spine on the telson is very short in $G$. intermedia, of: medium length in $G$. dispersa (about half as long as the next spine), and in G. squamifera it is longer still, being about two-thirds the length of the next spine.

All the above measurements refer to larvæ of the first zœa stage. The relative differences are stated to be constant for all the larval stages, but certainly they are most plainly marked in the young stages; and some little difficulty is experienced in distinguishing the late larval species. by this test. For this reason I have labelled the figure of the Stage IV telson (Pl. IV, Fig. 4) as belonging to Galathea sp.

\section{Literature.}

Bell, T. 1853.

Couch, R. Q. 1843.

Boas, J. E. V. 1830.

Sars, G. O. 1889.

Claus, C. 1876.

Williamson, H. C. 1910.

Claus, C. 1886.

Tribe THALASSINIDEA.

Species recorded in Plymouth Marine Invertebrate Fauna :-

Family AXIID A.

Calocaris Macandrea Bell.

Family CALLIANASSID $\#$.

Upogebia stellata (Mont.).

Other species recorded from south-west coast, but not mentioned in Plymouth Fauna List :-

Family AXIID E.

Axius styrhinchus Leach. 


\section{Family CALLIANASSIDA.}

\section{Upogebia deltura Leach. Callianassa subterranea Leach.}

The above five species have been recorded from the south coasts of Devon and Cornwall, and full accounts of all the adults have been published. The larvæ of this group, however, have not all been identified, or have, in some cases, been identified wrongly. This confusion is doubtless due partly to the difficulty of obtaining the mature females in a living condition owing to their fossorial habits, and partly to the difficulty of reproducing in the Laboratory sufficiently life-like conditions in which to hateh the larvæ from the berried females or to rear the living larvæ obtained from the tow-nets.

From larvæ taken in this way from the tow-nettings at the Plymouth Marine Laboratory I have succeeded in rearing specimens of four Thalassinideans as far as the first post-larval stage. Of these, two are Upogebia stellata Mont. and $U$. deltura Leach, which have been described in an earlier paper (Webb, 1919); while of the other two, one (Larva A) should be identified as the young stage of Callianassa subterranea Leach, and the other (Larva B) as that of Axius styrhinchus Leach. Of these four species, three (all but Larva A) have been successfully reared to a later stage.

Before describing the above forms it is necessary to call attention to some points in the related literature on which much confusion prevails.

Apparently the same larva has been described by Claus $(1876$, p. 44 , Figs. 14-18) as Hippolyte, by Cano (1891) as Axius styrhinchus and by Sars (1884) as Calocaris Macandrea.

The situation is still further complicated by Sars' description, which seems to be drawn from two different larvæ, one of which (Tab. 6 and 7) is very similar to, if not identical with, that described by Cano as Axius styrhinchus, while the other (Tab. 2) is a larva differing in many respects from the first, but stated by Sars to be an intermediate form between the larval and post-larval stages of the same species, although he did not actually obtain one stage from the other by moulting.

The first stages of this larva, described under different names by Claus, Cano, and Sars, occur quite frequently in the tow-nettings at Plymouth during the late summer, while the post-larval stage is also found there (Larva A in this paper), though not so frequently; but I have never found the "intermediate stage" stated by Sars to belong to the same species.

Moreover, both the last larval stage, which, according to Sars, immediately precedes this "intermediate stage," and the first post-larval, which succeeds it, have two pairs of large and well-developed uropods 
fully armed with plumose setæ (Tab. 7, Fig. 17); yet the so-called "intermediate stage" has uropods which are very small, entirely spineless and obviously in an undeveloped or a restigial condition (Tab. 2, Fig. 17).

It would be an extremely unlikely occurrence for an animal to acquire fully armed uropods during its larval existence, lose them for a single stage, and then re-acquire them in the following stage.

This "intermediate" larva of Sars also differs from the early stages described in other important points, such as the rostrum, the abdominal spines, and the shape of the telson.

I have now succeeded in obtaining the first post-larval stage (Larva A) direct from the earlier larval stages described by Sars, so that this moulting of the larva into a post-larval form provides definite proof that the "intermediate stage" does not really belong to this species at all, and that Sars has described two different larvæ as belonging to the same species.

This post-larval stage (Larva A) is described below, and clearly shows the characters of Callianassa; the larval stages, therefore, described as Calocaris by Sars and as Axius by Cano, must now be recognised as the young stages of Callianassa.

Williamson's attitude (1915) with regard to the identification of this larva is not easily understood, for he states that "the larva described by Claus as belonging to Hippolyte is an Axius larva, as is also the form described by Sars as Calocaris Macandrece," and then he proceeds to use Sars' figures as an illustration of the larva of Calocaris, having just stated them to be wrongly identified as such.

Claus (1876, Taf. VIII, Fig. 1) and Cano (1891, Tav. III, except the post-larval stage) have both published figures of yet another Thalassinid larva, which they have identified as Callianassa, but which should now be regarded as the unidentified larval form of some other Thalassinidean ; while the post-larval stage on Tav. III of Cano's paper is apparently the same as Larva A of this paper, and rightly regarded as Callianassa.

Bjorck (1913) has published a description of the young stage of Calocaris Macandrea, at a length of $8 \mathrm{~mm}$., and mentions that he has obtained a larval stage similar to the "intermediate stage" of Sars, but younger (apparently with the uropods still undeveloped, Taf. 1, Fig. 1). It seems probable, therefore, that the "intermediate stage" of Sars is truly a larval stage of Calocaris Macandrea, of which a younger and a postlarval stage are figured by Bjorck.

The fact that this larva has not been obtained in the Plymouth townettings is possibly accounted for by the fact that Calocaris Macandrea is an animal with a much deeper water habitat than most Thalassinideans. It has never been recorded from less than 25 fathoms, and has been 
obtained from as great a depth as 700 fathoms (Selbie, 1914), so that one would not expect its larvæ to be often washed so far inshore as Plymouth Sound.

The following table gives a list of references to the figures of various Thalassinid larvæ published in previous papers, together with their new identifications (if altered) :-

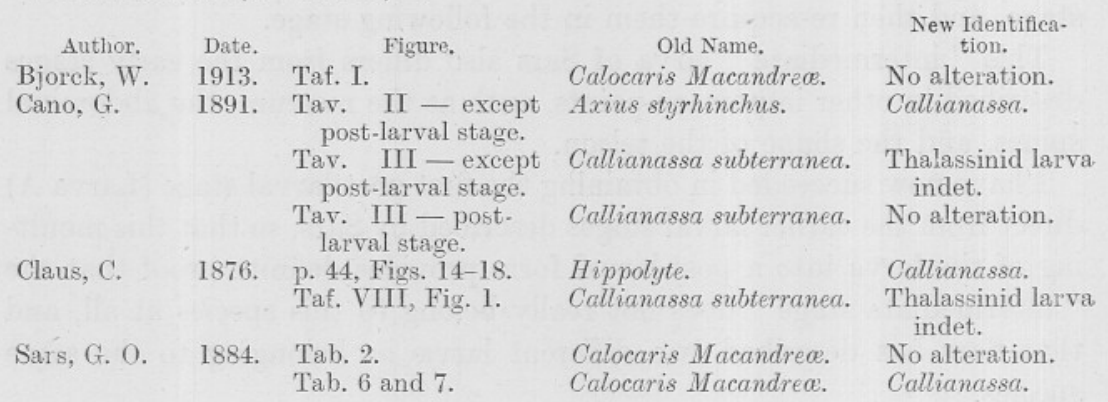

\section{Family CALLIANASSID AE.}

Species recorded in the Plymouth Marine Invertebrate Fauna :-

Upogebia stellata (Mont.).

Others species occurring at Plymouth :-

\section{Upogebia deltura Leach.}

Although only one species of this genus, U. stellata (Mont.), is recorded in the Plymouth Marine Invertebrate Fauna, the other species, $U$. deltura Leach, is also found, though more sparingly, in that district (De Morgan, 1910), and the larvæ of the two species occur in about equal abundance in the plankton of Plymouth Sound.

The larvæ of the two species are almost identical in appearance, and in some stages can only be distinguished with certainty by dissection. Their colouring is transparent, with scattered red chromatophores and dark eyes tinged with green.

The more minute differences of structure characterising the two species have been described in a previous paper (Webb, 1919), but one point of difference is afforded by the armature of the maxillipeds in the two species, as follows :-

Stage.

I and II.

III and IV. Second Maxilliped. Seta on
U. deltura. U. stellata.

Absent. Present.

Absent. Present. second joint of endopodite. 


\section{Distinguishing Features of the Four Larval Stages.}

Stage 1 . Caudal plate simple, bearing twelve spines; uropods absent. Stage II. Caudal plate simple, bearing fifteen spines; uropods absent.

Stage III. Telson and outer uropods well developed and armed with spines; inner uropods present, but small and spineless.

Stage IV. Both pairs of uropods well developed and armed with spines.

\section{Literature.}

Webb, G. E. 1919.

Larva A. Callianassa subterranea Leach.

The larval stages of this form have already been fully described by Sars (1884) under the name of Calocaris Macandrea. Figures of the first larval stage (PI. III, Fig. 2) and of the telson and uropods of the last larval stage (Pl. III, Fig. 5) are given here. The larva is perfectly transparent, and colourless save for a large branched red-and-yellow chromatophore on the dorsal region of the carapace, and a tinge of green over the eyes.

The First Post-larval Stage which moulted from the last larval stage is similar in general appearance to Upogebia at the same stage. The animal measures about $3.7 \mathrm{~mm}$. from the front of the eyes to the end of the telson; the body is very slightly compressed laterally, the carapace rounded and slightly concave behind, with the linea thalassinica and cervical groove well marked. The rostrum is a triangular projection which bends downwards in front of the eyes, which are short and thick and flattened on the inner side, so that they are pressed closely together in the middle line; the cornea is slightly pigmented.

The First Antenna has a three-jointed peduncle and two short flagella about as long as the distal joint of the peduncle. Both flagella are armed with scattered setæ, and the outer one is tipped with a group of æsthotases.

The Second Antenna consists of a two-jointed base with a short process on the outside representing the antennal scale, and a flagellum of about twenty-three joints which reaches well beyond the end of the carapace.

The Mandible is fairly well developed with a distinct palp.

The First Maxilla has its inner edge produced into a basal and a masticatory lobe, both bordered with short setæ; a weakly developed maxillary palp is present on the outer side of the masticatory lobe.

The Second Maxilla has four lobes on the inner margin, of which the anterior three are armed with setæ along the inner border ; the maxillary 
palp is armed with three setæ, and the long oval scaphognathite on the outer side is bordered with about thirty plumose setæ.

The First Maxilliped has the base produced on the inner side into two lobes, both bordered with setæ; the maxillary palp is large, with a row of ten plumose setæ on the outer edge. There is a large flattened epipodite on the outer side of the base.

The Second Maxilliped is slender and pediform, curved inwards and armed with setæ, especially on the inner edge ; there is a small epipodite on the outer side and a process representing the remains of the exopodite.

The Third Maxilliped is pediform (not operculiform, as in C. Stebbingi). The ischium and merus are broader than the carpus and propodite, and the whole limb is thickly armed with setæ, especially on the inner edge. The exopodite is represented by a spineless process on the outer surface.

The First Pereiopods or Chelipeds are only very slightly unequal in size at this stage. The carpus and propodite are large and massive, the ischium and merus more slender; the inner edge of the carpus and propodite is armed with long setæ, and there is a cluster of similar setæ at the base of the dactyl. The fixed finger is fully as long as the rest of the propodite, and the dactyl rather longer ; both dactyl and fixed finger are thickly set with long setæ.

The Second Pereiopods are also chelate; they are similar to the first pair, but smaller, and the propodite is proportionately shorter and broader. The dactyl is slightly longer than the fixed finger, and the whole limb is set with long setæ, particularly on its inner edge.

The Third Pereiopods have a rather slender ischium and merus, and a carpus which is narrow at the base but wider at the distal end where it joins the propodite, which is expanded into a flattened rectangular plate, thickly set with plumose setæ; the dactyl is triangular and also set with setæ. (The expansion of the propodite of the third pereiopod is a feature particularly characteristic of Callianassa.)

The Fourth and Fifth Pereiopods are slender and set with scattered setæ, particularly towards their distal ends; the fifth pereiopod has a tendency to be subchelate. The first four thoracic legs or pereiopods each bear a spineless process on the outer side of the base, representing the setose exopodite of the larva.

The Abdomen is long, slightly narrower at either end than in the middle and with moderate-sized abdominal pleura. There are only three pairs of pleopods, on abdominal segments three to five. This is a point of some importance, since even in the fully grown Callianassa the first two pairs of pleopods are stated to be much more slender than the last three (Selbie, 1914), and in a specimen of about three inches in length in the museum of University College there is as yet no trace of the first two pairs. 
Each pleopod has a short basal joint and two lobes bordered with plumose setæ; the inner lobe is shorter than the outer and bears an appendix interna on its inner margin.

Both pairs of uropods are well developed and set with plumose setæ ; the inner pair is slightly shorter than the outer.

The Telson is almost rectangular, bearing setæ on its posterior margin and a few spines at the posterior corners. It is slightly longer than the inner uropods (a point which, together with the pediform third maxillipeds, distinguishes this species from C. Stebbingi).

The striking resemblance which the above form bears to the adult Callianassa subterranea cannot fail to be noticed. Not only are the general features of the body, such as the presence of the linea thalassinica, the absence of a suture on the uropods, the weak development of the rostrum and the flattening of the eyes against each other, all extremely characteristic of that genus, but the resemblance even extends to the detailed structure of the appendages. The following points are of especial importance :-

(1) The antennular flagella are shorter than the peduncle.

(2) The ischium and merus of the third maxillipeds are broader than the carpus and propodite.

(3) There is no epipodite on the third maxillipeds or on the pereiopods, but a large one on the first maxillipeds and a small one on the second maxillipeds.

(4) The propodite of the third pereiopods is much flattened and expanded.

(5) The fifth pereiopods tend to be sub-chelate.

(6) There are no podobranchs on the pereiopods.

(7) Only the last three pairs of pleopods are present, on segments 3-5.

The only points in which this form differs from the descriptions of the adult $C$. subterranea are that the eyes are not well pigmented, and the chelipeds have not yet attained their adult structure: they are only slightly unequal, and the process on the merus, which is present on the cheliped of the adult, is not yet developed.

There is, however, no doubt that this form is the young stage of Callianassa subterranea Leach.

\section{Literature.}

Bjorck, W. 1913.

Borradaile, L. A. 1933.

Cano, G. 1891.

Claus, C. 1876.
Sars, G. O. 1884.

Selbie, C. M. 1914.

Williamson, H. C. 1915. 


\section{Larva B. Axius styrhinchus Leach.}

\section{First Larval Stage (Pl. III, Fig. 3).}

The larva in this stage measures about $8.7 \mathrm{~mm}$. from the tip of the rostrum to the end of the swimming-plate.

The Carapace, which is less than half as long as the abdomen, is somewhat compressed laterally, and produced in front into a long, slender, pointed rostrum, equal in length to the rest of the thorax; there is a well-developed sub-ocular spine on each side of the anterior border of the carapace.

The Antennce are long and narrow, very similar to those of Upogebia, and the antennal plate reaches about three-quarters of the length of the rostrum.

The First Antenna consists of a long, slender process with a terminal palp (the outer flagellum) bearing a group of æsthotascs, and a stout plumose seta representing the inner flagellum.

The Second Antenna has a basal joint, bearing on the outer side a long, slender antennal scale, tipped with a stout spine and bordered along its inner edge with a row of fourteen long, plumose setæ, and on the inner side a flagellum fully as long as the antennal scale.

The Mandible is well developed, with a double row of teeth along its inner edge and a well-marked mandibular palp.

The First Maxilla has an oval basal lobe, edged with a row of strong plumose setæ, and a stout masticatory lobe, bordered with strong teeth along its inner margin. The maxillary palp is well developed and bears four pairs of setæ on its inner edge.

The Second Maxilla is produced on its inner edge into four masticatory lobes, all thickly set with setæ, and a maxillary palp in front bearing five pairs of plumose setæ. On the outer edge is the exognath, a long, oval lobe edged with about thirty plumose setæ.

The First Maxilliped has its basal part produced on the inner side into two masticatory lobes, of which the distal is thickly set with long spines and the proximal bears about five long, plumose setæ. The palp is long and bears five pairs of setæ; the exopodite, which is about half as long again as the palp, ends in a cluster of six plumose setæ. On the outer side of the base is a long, oval, membranous expansion, the epipodite.

The Second Maxilliped has a two-jointed base and a five-jointed palp bearing setæ along both edges, and a cluster of strong spines at the end. The exopodite is twice as long as the endopodite or palp, and terminates in seven plumose setæ.

The Third Maxilliped is similar to the second, but the palp is longer ; 
the exopodite is about two-thirds the length of the palp, tipped with seven long and one short plumose setæ.

Thoracic Legs or Pereiopods. All five pairs of these are present, the first three pairs being already biramous and the first two chelate. The last two pairs are uniramous and carried pointing forwards beneath the body. All five pairs show indications of jointing beneath the larval cuticle.

The Abdomen is long and powerful; the second, third and fourth segments bear a backwardly directed median dorsal spine on the posterior border, and the fifth has two pairs of dorso-lateral spines on its hind border. The presence of these lateral spines on the fifth abdominal segment is interesting as indicating a possible affinity between the Thalassinidea and the Crangonidæ, in which family similar spines occur.

The four pairs of Pleopods are fairly large and already biramous, a remarkable fact for a larva in the first zoœa stage.

Uropods are absent; and the caudal Swimming-Plate is large, deeply cleft in the middle line and produced at the postero-lateral corners into a strong spine on each side. A similar but smaller spine occurs in the middle of the posterior border, the concave margin of which is armed with about thirteen setæ on each side.

This remarkable telson, reminiscent of that of the Norway Lobster, is very similar to one described by Thompson (1903) in another Thalassinid larva, i.e. Naushonia crangonoides, which occurs on the coasts of New England. The larva is almostly perfectly hyaline, with scattered red chromatophores on the rostrum, along the lateral borders of the carapace, on the ventro-lateral surface of the first five abdominal segments and on the telson. There is also an orange chromatophore at the base of the telson, a transverse band of luminous yellow on the thorax, and a tinge of pale blue over the eyes.

\section{Second Larval Stage.}

This stage moulted in the Laboratory from the preceding stage, which it closely resembles, the chief structural advance being the presence of six pairs of setose exopodites (from the first maxilliped to the third pereiopod) in place of the previous three pairs.

The larva now measures about $9 \cdot 2 \mathrm{~mm}$. in length.

The First Antenna has two transverse joints on the peduncle indicated by two groups of four short setæ on the outer margin; the outer flagellum bears a terminal bundle of æsthotases ; an inner flagellum is represented by a process tipped with a single seta, having two plumose setæ at its base and one more just below on the inner border of the peduncle.

The Second Antenna now has a two-jointed base, with a stout spine at 
the base of the antennal plate and a smaller one, with a seta, at the base of the flagellum. The antennal scale is unchanged, save for the addition of a single seta about half-way up its outer margin; and the flagellum is now half as long again as the scale.

The Mandible is similar to that of the previous stage, but the row of teeth is thicker on the inner edge.

The First Maxilla has the epipodite fringed with hairs, otherwise it is unchanged.

The Second Maxilla has five or six lobes on the inner side besides the maxillary palp; the most posterior lobe has an especially thick border of stout setæ.

The three pairs of maxillipeds are unchanged, save that the first pair now has a two-jointed base, and the exopodites of the second and third pairs each bear eight terminal setæ.

The first two pairs of Pereiopods are chelate, with setose exopodites about half as long as the endopodite, and tipped with seven and six plumose setæ respectively. The third pair has an exopodite tipped with five setæ; the fourth and fifth pairs are well developed and uniramous.

The armature of the abdominal segments has increased ; there are now three pairs of spines on the posterior border of the fifth segment and a small ventral spine on segments two to five.

The Pleopods are larger, but there is still no trace of uropods.

The Telson (Pl. III, Fig. 6) is similar to that of the previous stage, but somewhat more flattened along the posterior border.

\section{First Post-Larval Stage.}

This stage immediately follows the preceding larval stage, from which it moulted in the Laboratory.

The animal now no longer swims near the surface of the water, but sinks to the bottom, and if a suitable substance, such as fine sand or mud, is provided it commences to burrow. It measures $6-6.75 \mathrm{~mm}$. in length, and the carapace is somewhat compressed laterally.

The eyes are short and thick, but fairly well pigmented. The rostrum is triangular in shape, bluntly pointed and curved downwards. It bears about five serrate teeth and a few scattered hairs on its lateral margins, and extends about to the end of the second joint of the antennal flagellum.

The First Antenna has a three-jointed peduncle, tufted with setæ, of which the basal joint shows a swelling containing an otolith. The outer flagellum is six-jointed, bearing scattered setæ and ending in a short conical joint tipped with a strong seta. The fourth and fifth joints each bear a pair of æsthotases on their inner margins. The inner flagellum has five joints, of which the last is very short, and is sparsely set with setæ. 
The Second Antenna has a two-jointed base, produced into a short spine on the inner edge of the second joint. The flagellum is long and slender and comprises about twenty-two joints, set with scattered setæ ; the antennal scale is reduced to a small process on the outer side of the base.

The Mandible is large, with a well-developed masticatory edge and a three-jointed palp.

The First Maxilla has both masticatory and basal lobes well developed and fringed with setæ, which are particularly short and dense on the masticatory lobe. There is a distinct two-jointed palp with five setæ.

The Second Maxilla has four masticatory lobes, of which the basal one is the largest, and all of which are densely fringed with setæ. The maxillary palp bears four setæ, and on the outer side there is a long scaphognathite fringed with about thirty-five plumose setæ.

The First Maxilliped has the masticatory lobes on its inner edge armed with a dense row of plumose setæ. The exopodite is curved, with ten setæ along its outer border; the endopodite, or palp, is two-thirds the length of the exopodite and almost spineless. There is a large bilobed epipodite, and the basal joint bears gill processes.

The Second Maxilliped has a two-jointed base - the proximal joint with gills on its outer border. The exopodite is rather long and curved, with a few terminal setæ. The endopodite is five-jointed, rather shorter than the exopodite and fairly thickly set with setæ, especially on the inner border.

The Third Maxilliped is similar in general form to the second maxilliped, but the exopodite is tipped with six terminal setæ, and the endopodite is long and pediform, all the five joints being set with setæ, and the inner edge of the ischium or proximal joint bearing a row of seven flattened teeth.

The First Thoracic Leg or Pereiopod is chelate, very similar to that of Upogebia deltura, but with the dactyl longer than the fixed finger. A small process on the outer side of the base represents the exopodite. Each thoracic leg bears a pair of gills on the outer side of the basal joint.

The Second Pereiopod is chelate and similar to the first, but more slender. Both the second and third pereiopods bear a rudiment of the exopodite.

The Third, Fourth and Fifth Pereiopods are rather long and slender, and terminate in a slender point.

There are four pairs of Pleopods, each of which consists of a basal joint and two rami fringed with long plumose setæ. The inner ramus is rather longer than the outer, and bears an appendix interna on its inner edge.

There are two pairs of Uropods, the inner slightly the longer, and both fringed with long plumose setæ. There is no suture on either uropod. 
The Telson is roughly oblong, with the posterior edge rounded and slightly indented in the middle line. The whole of the posterior margin is thickly set with setæ, and a short spine occurs on the lateral edge.

On August 30th, 1920, I obtained a specimen of the above species in the first larval stage, taken alive from a tow-netting at Plymouth. It was isolated in a jar of fresh sea-water, and on September 2 nd it moulted into the second larval form described above. On September 7 th it moulted again into the first post-larval stage. It was now placed in a shallow dish with the bottom covered with a layer of fine sand and organic debris from one of the aquarium tanks, and almost immediately started to burrow. The following day a drawing of the burrow was made, and showed a round aperture, about $1 \mathrm{~mm}$. across, surrounded by a raised margin of sand and mud. The animal remained completely hidden in the burrow, and was not disturbed again until November 20th, when it died and was then taken out and preserved.

On examination it proved to exhibit almost all the characters of an adult female Axius styrhinchus. I have carefully compared it with the excellent descriptions of this species given by Borradaile (1903) and Selbie (1914), and find that, with the exception of certain very minor points enumerated below, which would probably not be developed in a very young specimen such as this, it agrees in every way both with the text description and the accompanying figures. The absence of the linea thalassinica and the size of the abdominal pleura place it in the family Axiidæ, while the lateral compression of the body and the absence of a median dorsal ridge on the carapace, and of a suture on the uropods, indicate that it belongs to the genus Axius.

In the general body-form, the shape and armature of the rostrum, the carapace, the abdominal pleura, and the telson, as well as the size and pigmentation of the eyes, which are half covered by the rostrum, it agrees exactly with Axius styrhinchus.

The structure of the antennæ, of the mouth parts and the thoracic and abdominal appendages is (with the exception of the few points mentioned below) identical with that of the adult Axius; while the presence of the peculiar structure situated between the coxæ of the fourth pereiopods and carefully described by Selbie (1914) indicates that the present specimen is a female and is of some interest in showing at what an early stage the secondary sexual characters are developed.

The following are the minor points on which the present specimen differs from that of Selbie's description :

The fringe described as present on the last three peduncular joints of the second antenna is absent. The anterior chelipeds have not yet attained their full development-the left and right chelipeds are still 
about the same size ; the carpus is only fairly short; the palm is nearly twice as long as the fingers (not one and a half times, as in the adult), and the crushing tubercles and fringe of setæ are not fully developed. The distribution of setæ on all the thoracic limbs is not so thick as in the adult, and the uropods are barely as long as the telson.

The rearing of this young form from the larva proves conclusively that the species described above is the true larval form of Axius styrhinchus Leach.

Borradaile. $1903 . \quad$ Thompson, M. T. 1903.

Selbie. 1914.

Family PAGURID E.

Species recorded in Plymouth Marine Invertebrate Fauna :-

Eupagurus Bernhardus (Linnæus).

Eupagurus cuanensis (Thompson).

Eupagurus Prideauxi (Leach).

Eupagurus sculptimanus (Lucas).

Diogenes varians Costa.

Anapagurus lavis (Thompson).

Features Characteristic of these Larve of Pagurid

(1) Rostrum. Long and pointed, reaches beyond first antenna.

(2) Eyes. Large and oval.

(3) Carapace. Relatively broad and short; concave behind, and terminating postero-laterally in a sharp point; no fringe of spines on either side (cf. Galatheidæ).

(4) Telson. Roughly spatulate, with truncated posterior margin.

(5) Setose Exopodites. Three pairs (first to third maxilliped) in Stage IV larva.

Distinguishing Features of the Four Larval Stages.

Stage I. Caudal plate simple, bearing twelve spines; uropods absent.

Stage II. Caudal plate simple, bearing fourteen spines; uropods absent.

Stage III. Telson and outer uropods well developed and armed with spines; inner uropods represented by a small spineless process at root of outer pair. Thoracic legs moderately developed.

Stage IV. Telson and uropods as in Stage III. Developing thoracic legs much larger, extending back to cover all but last two pairs of pleopods. 
Of the six Plymouth species of Paguridæ, the larvæ of only two have been identified with certainty, namely, Eupagurus Bernhardus and Eupagurus Prideauxi.

These may be distinguished from one another by the following features :-

(1) Length.-Eupagurus Bernhardus measures $3 \frac{1}{2} \mathrm{~mm}$. in its first larval stage; Eupagurus Prideauxi is considerably shorter. The additional length of $E$. Bernhardus is chiefly due to the excessive length of the last abdominal semite (not yet separated from the telson).

(2) Telson.-This is shorter and more triangular in E. Prideauxi, especially in Stage I. The third spine from the outside is equal in length to the other spines and jointed to the telson; while in E. Bernhardus there is no suture between the third spine and the telson, and the spine itself is half as long again as the inner spines.

The larva of Eupagurus Bernhardus is almost transparent, with a redand-yellow chromatophore on the dorsum, the mouth parts flecked with deep crimson, and a conspicuous orange chromatophore (most noticeable in late larval stages) on the developing chela of the first leg. The eye is dark, with glints of luminous yellow.

The fourth larval stage in the Paguridæ is followed by a transitional stage known as the "Glaucothöe." At this stage the animal alternately walks on the bottom, and swims actively by means of its four pairs of pleopods. The asymmetry so characteristic of the adult makes its first appearance at this stage, in that the right uropod is now smaller than the left. During this stage the liver, excretory bladder and gonads shift to the abdomen, the right pleopods disappear and the left degenerate. At the next moult the animal assumes more or less completely the adult form and seeks a shell in which to make its home.

\section{Literature.}

Bouvier, E. L. 1891.

Issel, R. 1910.

Mayer, P. 1877.

Jac'sson, H. G. 1913.

Sars, G. O. 1889.

\section{Family PORCELLANIDA.}

Species recorded in Plymouth Marine Invertebrate Fauna :-

$$
\begin{aligned}
& \text { Porcellana longicornis (Linnæus). } \\
& \text { Porcellana platycheles (Pennant). }
\end{aligned}
$$

The larvæ of the two species are very similar, but $P$. platycheles is slightly the larger, measuring $6 \mathrm{~mm}$. in the first stage; while $P$. longicornis measures $5 \mathrm{~mm}$. in the same stage. 
The exact number of larval stages has not been ascertained, but the larvæ present several interesting developmental features. The rostrum is produced into a very long spine, fully twice as long as the rest of the body; and the carapace is produced backwards into two spines, about half the length of the rostral spine. This feature renders the larvæ easily distinguishable in the tow-nets, but it also adds to the difficulty of rearing the larvæ under artificial conditions, as the long spines are easily caught in the surface film, so that the animal cannot free itself.

The last larval stage, preceding the first post-larval, has pleopods but no uropods, nor has the number of setose exopodites increased from the original two (first and second maxillipeds) of the first stage; although the terminal setæ on the exopodites have increased in number from four to eleven. The larva is transparent, with bright red and yellow pigment in the region of the mouth parts, and red chromatophores on the sides of the abdominal segments. The rostral spine is tipped with red, as are also the posterior carapace spines ; and two bands of reddish or yellowish colour are also present on the more proximal part of the rostrum.

The eyes are dark brown in colour, and the telson sometimes bears a yellowish tinge.

\section{Literaiure.}

Faxon, W. 1879.

Sars, G. O. 1889. 


\section{LITERATURE.}

1853. Bell, T. "British Stalk-eyed Crustacea."

1913. Bjorck, W. "Beiträge zur Kenntnis der Decapoden metamorphose II über das post-larvale Stadium von Calocaris Macandrece Bell." Archiv. für Zool., Bd. 8, No. 7.

1891. Brooks, W. K., and Herrick, F. H. "The Embryology and Metamorphosis of the Macroura." Mem. Nat. Acad. Sci., Washington, Vol. V, p. 321.

1880. Boas, J. E. V. "Studier over Decapodernas Slaegtskabsforhold. Avec un resumé en Français. Recherches sur les affinités des Crustacés décapodes." Kgl. Danske. Vidensk. Selsk. Skr., Serie 6, naturv. og. mathem., Afd. 1, p. 25. Auszug. in Journ. Roy. Mic. Soc., Ser. 2, Pt. I, p. 450. 1881.

1903. Borradaite, L. A. "On the Classification of the Thalassinidea." Ann. Mag. Nat. Hist., Ser. 7, Vol. XII, p. 534.

1891. Bouvier, E. L. "Les Glaucothoés sont elles des Larves de Pagurus?" Ann. Sci. Nat., Ser. 7, Zoology, T. XII, p. 65.

1914. _ _ Recherches sur le Développement post-embryonnaire de la Langouste commune (Palinurus vulgaris). Journ. Mar. Biol. Assoc., Vol. X, p. 179.

1891. Cano, G. "Svilluppo postembrionale della Gebia, Axius, Calianassa e Calliaxis. Morfologia dei Talassinidi." Boll. Soc. Nat. in Napoli, Ser. I, Vol. V.

1863. Claus, C. " Über einige Schizopoden und niedere Malacostraken Messinas." Ze.t. Wiss. Zool., Vol. XIII, p. 422.

1876. _ _ "Untersuchungen zur Erforschung der genealogischen Grundlage des Crustaceen Systems." Wien.

1886. — “ "Beiträge zur Morphologie der Crustaceen." Arb. Zool. Inst. Wien., Vol. VI, Taf. VI, Fig. 49. (Galathea intermedia ?)

1843. Couch, R.Q. " On the Metamorphosis of the Decapod Crustacea." 11th Ann. Rep. Roy. Cornwall Polytech. Soc.

1844. — " On the Metamorphosis of the Crustaceans, including the Decapoda, Entomostraca, and Pycnogonidæ." 12th Ann. Rep. Roy. Cornwall Polytech. Soc.

1899. Coutière, H. "Les Alpheidæ, morphologie externe et interne, formes larvaires, bionomie." Ann. Sci. Nat., Ser. 8, Zool., Tome IX, pp. 1-599. 
1907. Coutière, H. "Sur quelque formes larvaires enigmatiques d'Eucyphotes, prevenant des Collections de S. A. S. le Prince de Monaco." Bull. Inst. Oceanogr., Monaco, No. 104.

1891. Cunningham, J. J. " On the development of Palinurus vulgaris, the Rock Lobster, or Sea Crayfish." Journ. Mar. Biol. Assoc., N.S., Vol. II, No. 2, p. 141.

1910. De Morgan, W. "On the Species of Upogebia stellata and Gebia deltura. Journ. Mar. Biol. Assoc., Vol. VIII, p. 475.

1870. Dohrn, A. "Untersuchungen über Bau und Entwicklung der Arthropoden. No. 6. Zur Entwicklungsgeschichte der Panzer krebse (Decapoda loricata)." Zeit. Wiss. Zool., Bd. 20, p. 248.

1879. Faxon, $W$. "On some young stages in the development of Hippa, Porcellana and Pinnixa." Bull. Mus. Comp. Zool. Harvard, Cambridge (Mass.), Vol. V, p. 303.

1903. Gurney, R. "The Larvæ of Certain British Crangonidæ." Journ. Mar. Biol. Assoc., Vol. VI, p. 595.

1903. _ " " The Metamorphoses of the Decapod Crustaceans Egeon (Crangon) fasciatus Risso and Egeon (Crangon) trispinosus (Hailstone)." Proc. Zool. Soc., 1903, Vol. II, p. 24.

1910. Issel, $R$. "Ricerche intorno alla biologia et alla morfologia dei Crostacei decapodi. Parte I. Studi sui Paguri." Arch. Zool., Vol. IV, Fasc. 3, Napoli, p. 335.

1913. Jackson, H. G. L.M.B.C. Memoirs. No. XXI. Eupagurus. Liverpool Proc. Trans. Biol. Soc., 27, p. 495.

1902. Lo Bianco, S. "Le pesche pelagische. abissali eseguite dal 'Maia " nelle vicinanze di Capri." Mitt. Zool. Stat. Neapel., Vol. XV, p. 413.

1904. —— "Beiträge zur Kenntnis des Meeres. I. Tiefsee-Fischerei der Maia.” Jena, 1904. p. 32, Fig. 41, Taf. XI.

1877. Mayer, $P$. "Zur Entwicklungsgeschichte der Dekapoden." Jena, Zeit. f. Naturw., Bd. 11, p. 188.

1881. — "Carcinologische Mitteilungen. IX. Die Metamorphose von Palcemonetes varians Leach." Mitt. Zool. Stat. Neapel, Vol. II, Pt. II, p. 197.

Auszug in Journ. Roy. Mic. Soc., Ser. 2, Vol. I, p. 41.

1904. "Plymouth Marine Invertebrate Fauna." Journ. Mar. Biol. Assoc., Vol. VII, No. 2.

1874. Sars, G. O. "Om Hummerens (H. vulgaris) postembryonaleUdvikling." Forhandl. Vidensk. Selsk., p. 1. 
Auszug in Amer. Journ. Sci. Arts., Ser. 3, Vol. IX, 1875, under S. J. Smith, "The Development of the European Lobster."

1884. Sars, G. O. " "Bidrag til Kundskaben om Decapodernes Forvandlinger. I. Nephrops, Calocaris, Gebia." Arch. Math. Naturw., IX, p. 182.

1889. _ _ " Bidrag til Kundskaben om Decapodernes Forvandlinger.

II. Lithodes, Eupagurus, Spiropagurus, Galathodes, Galathea, Munida, Porcellana (Nephrops)." Arch. Math. Naturw., XIII, p. 133.

1890. — _ " Bidrag til Kundskaben om Decapodernes Forvandlinger.

III. Fam. Crangonidæ." Arch. Math. Naturw., XIV, p. 132.

1900. — " Account of the Post-embryonal Development of Pandalus borealis $\operatorname{Kr} \phi y e r$, with remarks on the Development of cther Pandali, and description of the adult Pandalus borealis." Norwegian Marine Investigations, Vol. I, No. 3.

1906. _ _ "The Post-embryonal Development of Athanas nitescens Leach.” Arch. Math. Naturw., XXVII, No. 10.

1911. _ " Account of the Post-embryonal Development of Hippolyte varians Leach." Arch. Math. Naturw., XXXII, No. 7.

1914. Selbie, C. M. "The Decapoda Reptantia of the Coasts of Ireland Pt. I : Palinura Astacura and Anomura (except Paquridæ)." Fisheries Ireland Sci. Invest., 1914, I (1914).

1912. Sollaud, E. "Les Metamorphoses du Bouquet." Comptes renđus Acad. Sci. Paris, Tome 154, p. 664.

1836. Thompson, J. V. "Memoir on the Metamorphosis in the Macrura or Long-tailed Crustacea, exemplified in the Prawn." Edinburgh New Philos. Journ., Vol. XXI, p. 221.

Auszug in Proc. Roy. Soc., Vol. III, 1836, p. 371.

1903. Thompson, M. T. "A rare Thalassinid (Naushonia Crangonoides) and its larva." Boston (Mass.) Proc. Soc. Nat. Hist., 31, p. 1, 3 Pls.

1919. Webb, G. E. "The Development of the Species of Upogebia from Plymouth Sound." Journ. Mar. Biol. Assoc., Vol. XII, No. 1.

1901. Williamson, H. C. "On the larval stages of Decapod Crustacea. The Shrimp: Crangon vulgaris Fabr."

1905. — " A Contribution to the Life History of the Lobster (Homarus vulgaris)." Ann. Rep. Fish. Bd. Scotland, Vol, 23, Pt. 3, p. 65 . 
1910. Williamson, H. C. "Report on the larval and later stages of Portunus holsatus Fabr., Portunus puber L., Portunus depurator Leach, Hyas araneus (L.), Eupagurus Bernhardus L., Galathea dispersa Spence Bate, Crangon trispinosus (Hailstone), Cancer pagurus L." Fisheries Scotland Sci. Invest., 1909 (Dec., 1910), (sic) London, 1911. 5 pls. Issued separately as Stationery Office publication.

1915. — "Decapoden. I. Teil (Larven)." Nordisches Plankton. VI. Kiel and Leipsig, 1915. 


\section{Plate I.}

FrG. 1. Leander squïlla.

2. Pandalus Montagui.

, 3. Hippolyte varians.

, 4. Athanas nitescens.

"5. Palamonetes varians.

6. Pandalus brevirostris.

7. Hippolyte sp. (probably $H$. varians).

8. Athanas nitescens.
First Larval Stage. $\times 38$.

, ,,$\times 31$

" $, \quad, \quad \times 71$

Third " , $\times 41$,

Fourth " "Telson and Uropods. $\times 71$.

,"

Late $\quad ", \quad ", \quad ", \quad, \quad$,

" $", \quad$ " 
PLATE I.

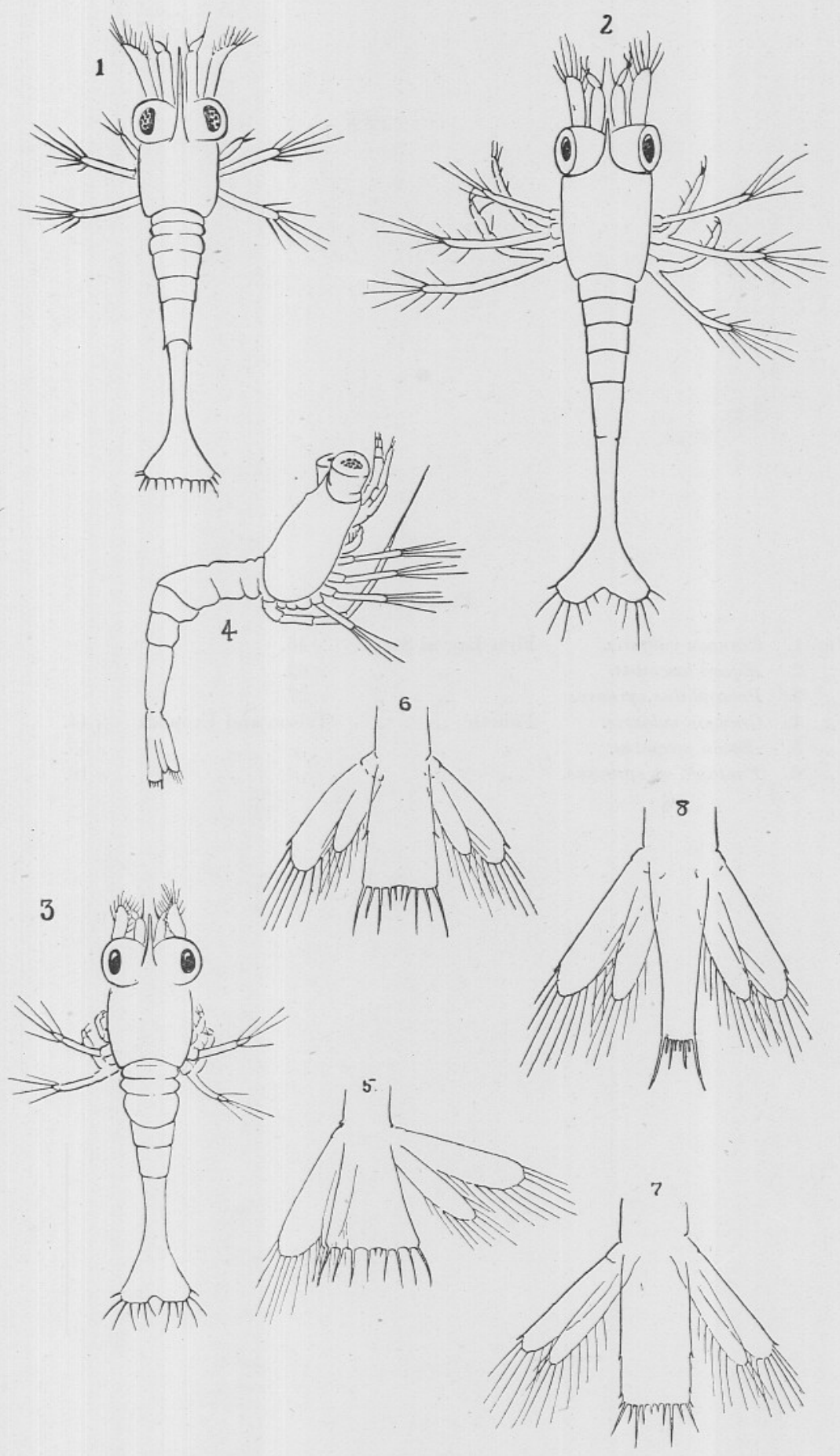

G. E. Webb. Larva of Decapoda. 
垡- 
PLATE II.

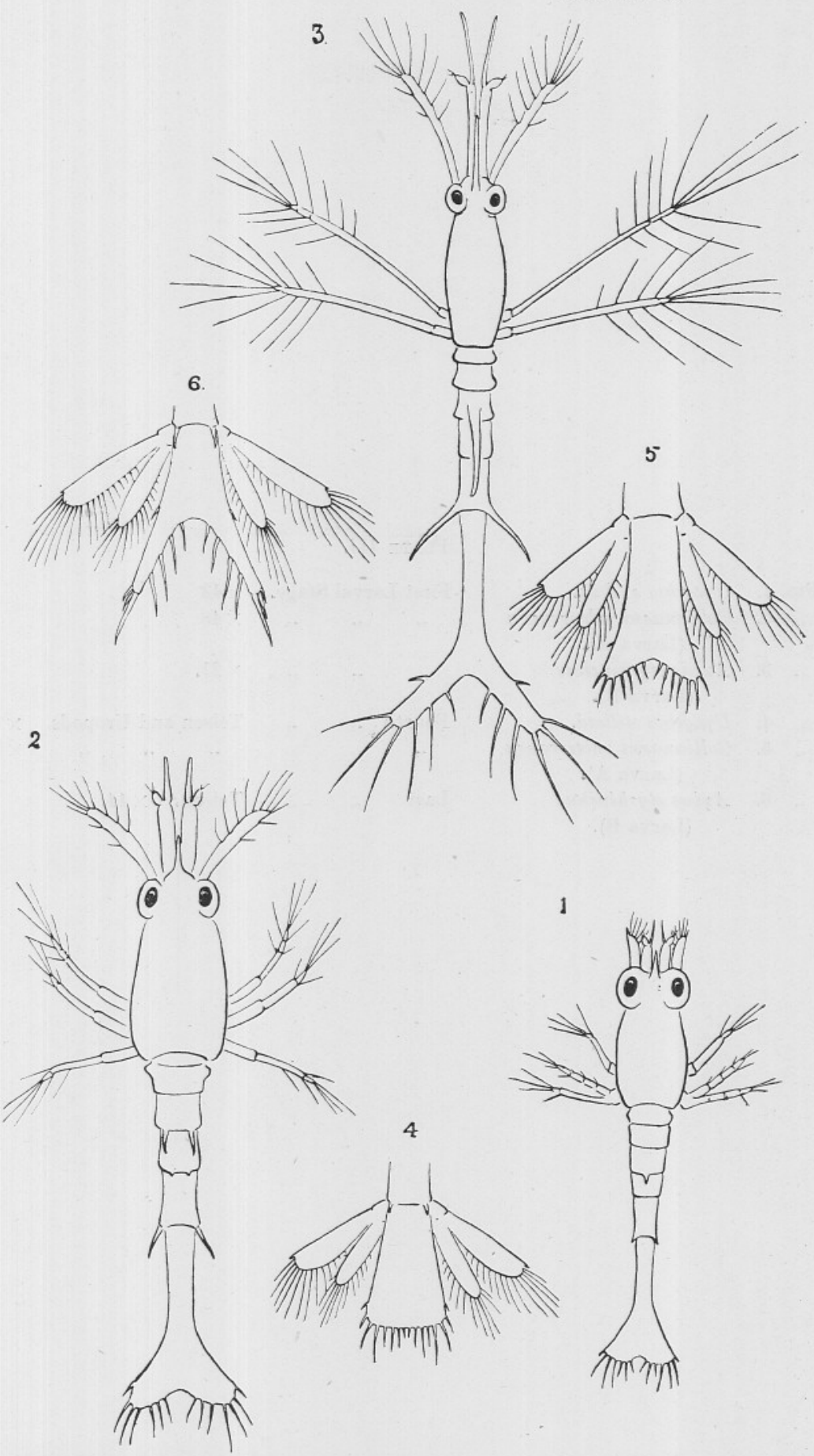

G. E. Webr. Larre of Decapoda. 


\section{Plate III.}

FIG. 1. Upogebia s'ellata.

,2. Callianassa subterranea

(Larva A).

, 3. Axuis styrhinchus (Larva B).

4. Upogebia stellata.

, 5. Callianassa subterranea (Larva A).

, 6. Axius styrhinchus (Larva B).

$\begin{array}{cc}\text { First Larval Stage. } & \times 43 \\ & \times 48\end{array}$

" , ,,$\quad \times 21$.

Fourth " , Telson and Uropods $\times 71$.

" , , , , , , $\quad \times 71$.

Last , , , Telson. $\times 44$. 
PLATE III.
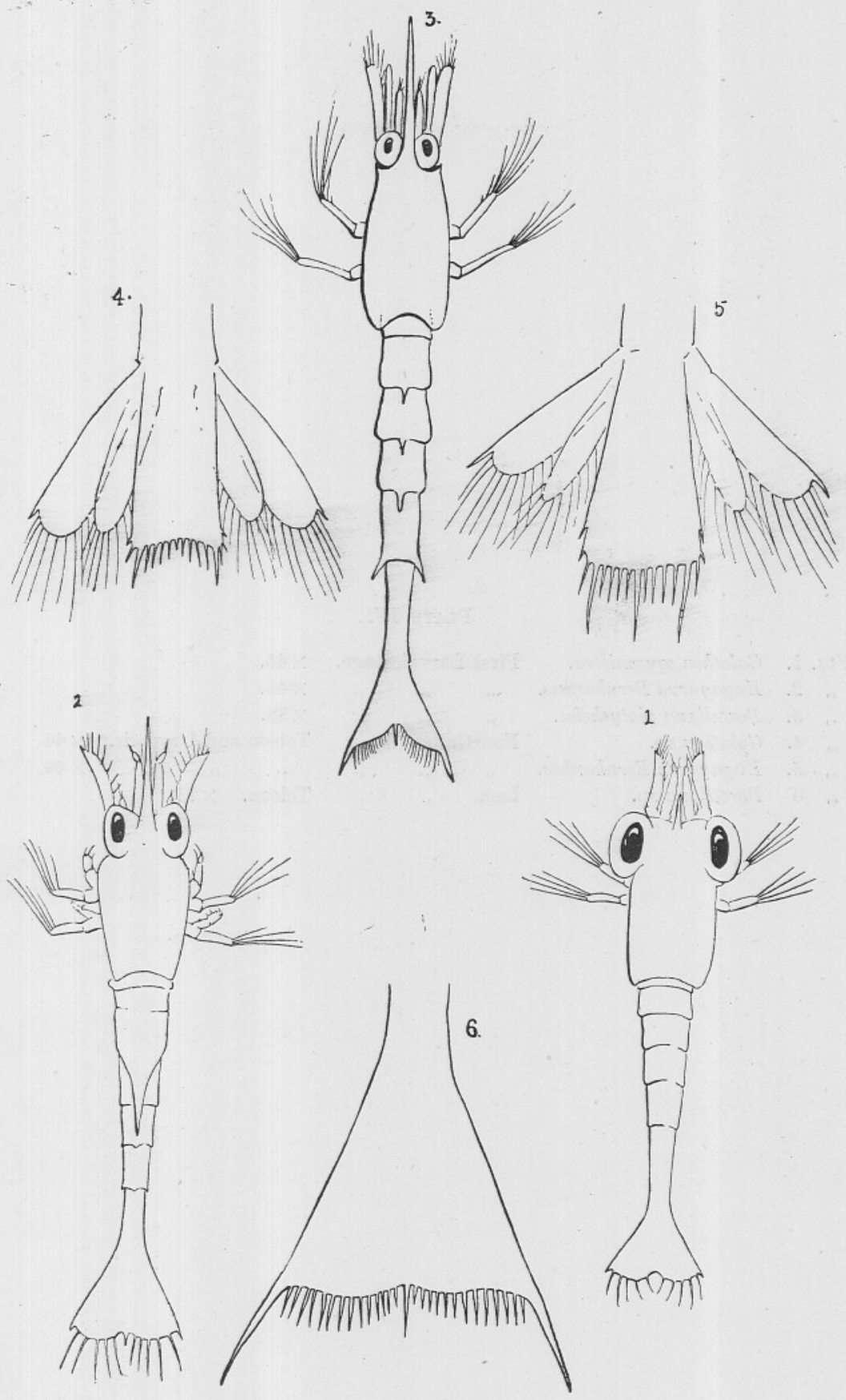

G. E. WreBb. Larve of Decapoda, 
Plate IV.

FIG. 1. Galathea squamifera. First Larval Stage. $\times 45$.

"2. Eupagurus Bernhardus. , , , ", $\times 44$.

" 3. Porcellana platycheles. , ", , $\quad \times 38$.

" 4. Galathea sp. Fourth ," " Telson and Uropods. $\times 44$.

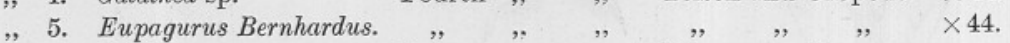

" 6 Porcellana sp. Last ", ., Telson. " $\times 71$. 
- PLATE IV.
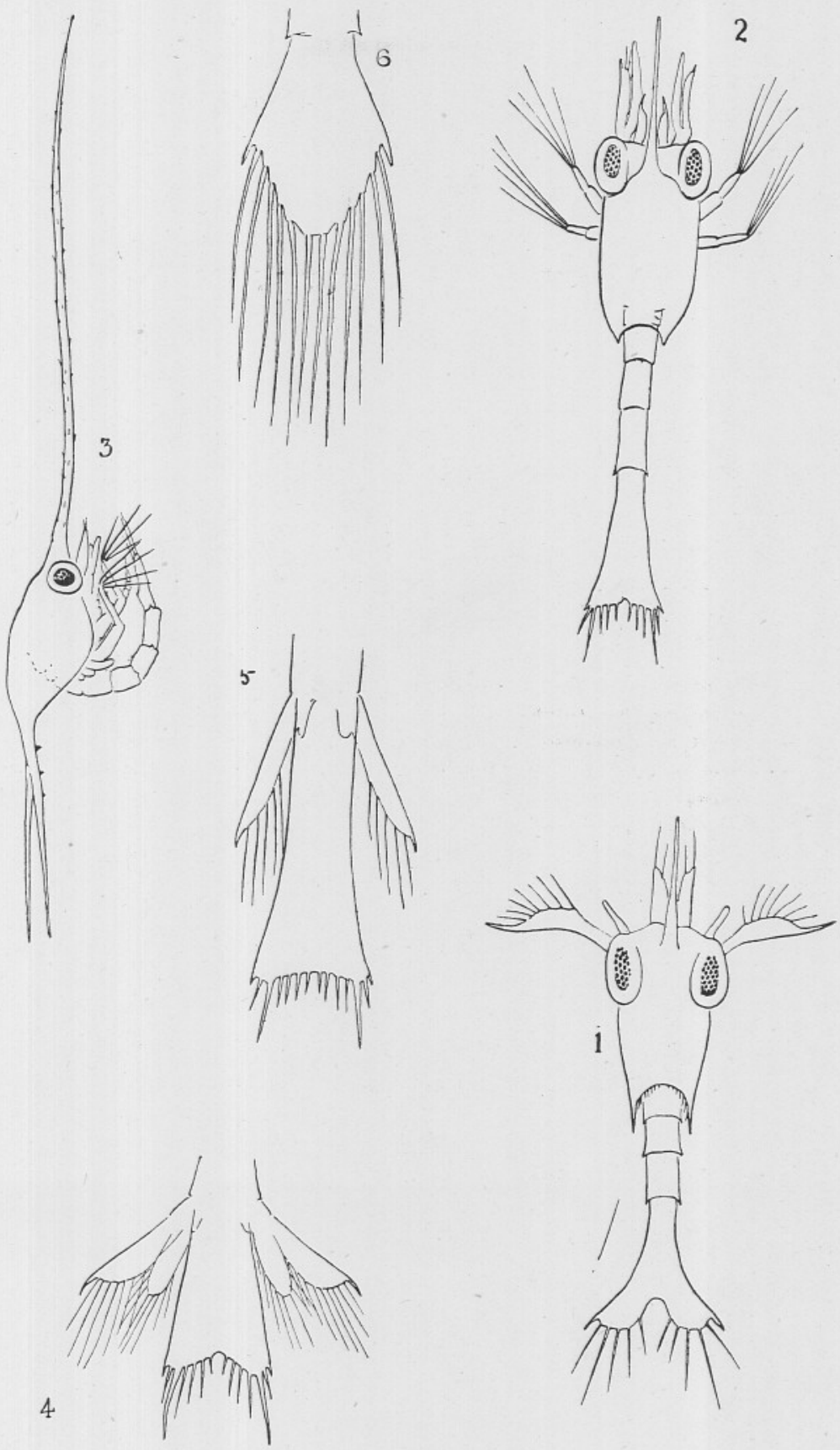

G. E. WebB. Larve of Decapoda. 